\title{
Importance of Genetic Evaluation of Dairy Cattle for Functional Traits: A Review
}

\author{
B. Balasundaram, A.K. Thiruvenkadan ${ }^{1}$, N. Murali', \\ J. Muralidharan'ㄹ, D. Cauveri ${ }^{3}$, R. Saravanan ${ }^{1}$
}

10.18805/IJAR.B-4340

\begin{abstract}
The general practice of selection of dairy animals concentrating high milk production has unwanted consequences like occurrence of health problems and fertility issues. Functional traits, including health and fertility, have significant genetic association with production and reproduction performance traits. Functionally superior dairy cows are healthy and sustained producers of healthful food for calves and human consumption. Improvement in functional traits rises the economy of dairy farmers by reducing the cost of input. These facts emphasised the inclusion of functional traits along with other economically important traits in selection criteria for the improvement of dairy animals. Hence, most of the dairy advanced countries have included genetic evaluation of functional traits as a routine practice in their dairy cattle selection programmes. In India, comparatively limited works have been carried out on functional traits and it suggested exploring more on this area for further development of the dairy sector. This review details the importance of inclusion of functional traits in genetic evaluation of dairy cattle for overall development of the dairy industry.
\end{abstract}

Key words: Calving traits, Estimated breeding value, Feet and leg traits, Fertility, Heritability, Total merit index, Udder health traits.

Milk production traits are highly focussed in dairy cattle breeding programmes due to their direct relationship with the economy of dairy farming. This kind of single trait selection improves the milk production potential of cows with some adverse effects on health and reproduction capacity of animals. Repeated practice of single trait selection and multi traits selection omitting health traits in dairy cattle improvement programmes of various countries has resulted in high disease losses, increased reproductive failure, extended cost of maintenance of animals and higher culling rate. Higher incidence of health problems as a consequence of genetic improvement for milk production indicates the existence antagonistic genetic relationship between milk production traits and disease resistance (Simianer et al. 1991). This relationship signifies the importance of redesigning of traditional selection programmes.

Groen (1996) defined the term functional traits as the characters of animals which increases the efficiency not by higher output of product but by reduced cost of input'. Functional traits are classified into different categories namely calving abnormalities, udder health traits, fertility traits, metabolic stress, feet and leg problems and longevity (ICAR, 2019). Dystocia and stillbirth are two economically important calving traits regularly used in genetic evaluation of dairy animals in dairy advanced countries. Intensity of dystocia is measured as maternal calving ease which shows the easiness of cows giving birth, and direct calving ease which is referred to calf. Udder health traits include udder conformation traits, incidence of clinical mastitis and somatic cell score. The traits included in fertility category are nonreturn rate, calving interval, days open and incidence of fertility disorders like retained placenta, cystic ovary and
1Department of Animal Genetics and Breeding, Veterinary College and Research Institute, Tamil Nadu Veterinary and Animal Sciences University, Namakkal-637 002, Tamil Nadu, India.

${ }^{2}$ Mecheri Sheep Research Station, Tamil Nadu Veterinary and Animal Sciences University, Pottaneri, Salem-636 453, Tamil Nadu, India. ${ }^{3}$ Department of Animal Genetics and Breeding, Madras Veterinary College, Tamil Nadu Veterinary and Animal Sciences University, Chennai-600 007, Tamil Nadu, India.

Corresponding Author: B. Balasundaram, Department of Animal Genetics and Breeding, Veterinary College and Research Institute, Tamil Nadu Veterinary and Animal Sciences University, Orathanadu614 625, Tamil Nadu, India. Email: balasundaram.b@tanuvas.ac.in

How to cite this article: Balasundaram,B., Thiruvenkadan, A.K., Murali, N. Muralidharan, J., Cauveri, D. and Saravanan, R. (2021). Importance of Genetic Evaluation of Dairy Cattle for Functional Traits: A Review. Indian Journal of Animal Research. DOI: 10.18805/ IJAR.B-4340.

Submitted: 23-10-2020 Accepted: 18-03-2021 Online: 29-04-2021

metritis. The functional traits, feed efficiency and body condition score are considered as metabolic stress traits. The common feet and leg traits used in genetic evaluation of dairy animals are feet and leg conformation, locomotion and clinical incidence of claw diseases. Longevity of dairy animals may be true or functional (Ducrocq, 1988). In case of true longevity, level of milk production is the sole cause of disposal whereas in functional longevity, disposal reasons other than milk production are considered. Along with the categorised traits, temperament traits and other health disorders have also been considered for assessing the functional efficiency of the animals. Genetic inadequacy in 
dairy animals for functional traits may affect the wellness of animals, economy of farmers and health of consumers of dairy animal produce. In this review, the essentiality of genetic improvement of dairy animals for functional traits is focused in detail.

\section{Importance of functional traits}

In the recent past, the interest level of consumers to know the source of food and their awareness on healthy foods have been risen considerably. Consumers always prefer to get healthful foods. Unhealthy animals may not produce healthy food. Health disorders like feet and leg problems have huge negative impacts on welfare of dairy animals and healthy food production (Huxley, 2013). Further, the effects of drugs used in animal treatment like development of antibiotic resistance, have considerably influenced the food choice of people in developed countries. These concerns of consumers demand the dairy industry to give more importance on welfare and health of animals (Boettcher, 2005).

Two important factors which affect the economy of dairy farming are quantity of production and cost of production. Functional traits are economically more connected with both the factors. Inferiority in dairy animals for functional traits inflates the disease losses and shorten the period of production to reduce quantity of yield. The reasons of economic losses due to abnormal calving include increased numbers of days open, reduced longevity, less milk yield and calf loss (Bicalho et al. 2008). Kumar et al. (2017) assessed the effect of calving abnormalities and found declining trend of production and reproduction performances in Frieswal cows that experienced an abnormal parturition. Fertility problems in dairy animals may be arisen as a consequence of abnormal calvings. Fertility problems reduces the profit to farmers in dairy farming through the means of additional number of inseminations, increased cost of treatment, extended lactation length with less production and more maintenance cost, modified performance in subsequent lactations and higher culling rate (Boichard, 1990). Similarly, udder health problems cause economic losses to the farmers through their consequences viz., reduction in quantity and quality of milk produced and expenses of labour, treatment and diagnostics (Hogeveen et al. 2011). An economic study on mastitis in Karan Fries cows by Jingar (2013) showed the average loss in milk yield per day, average mastitis days and average production loss as 4.45 to $5.40 \mathrm{~kg}, 15.10$ to 17.76 days and Rs. 754.80 to 1020.24 respectively.

Metabolic stress in dairy animals, a result of inefficient feed utilization, escalates the cost of production through rising health and fertility issues and lessening milk production and longevity (Wathes, 2012). Feet and leg problems increase the loss to the dairy farmers via, the treatment cost, less milk production, reduction in fertility, and expenses associated with culling and replacement (Huxley, 2013). An association study on claw disorders and milk losses by Charfeddine and Perez-Cabal (2017) estimated the loss of energy corrected milk in affected cows per day as 1.47 to $2.66 \mathrm{~kg}$. Functional longevity, a functional trait well associated with all other functional traits, exhibits its effect on economy of dairy farming through cost of rising or purchasing of replacement cows. Hence, the inclusion of functional traits in selection criteria is becoming essential for real improvement of dairy animals and dairy production system.

\section{Recording of data for genetic evaluation of functional traits}

The important sources of information on animal health and conformation are veterinarians, animal owner or producer and expert groups. Details of animal assessment by veterinarian, veterinary diagnosis and treatment registers, observations of owners and information from experts on specific problems are considered for recording of health traits (ICAR, 2019). The recorded information may be classified into the categories of direct and indirect data. The direct data includes diagnoses or observations of diseases and findings indicative of diseases from clinical signs whereas the indirect data comprises indicator traits of diseases like somatic cell count for subclinical mastitis and body condition score for metabolic stress. Recording of artificial insemination dates, calving dates, date of cessation of lactation and pregnancy diagnosis are essential for estimation of some fertility traits like non-return rate, inter calving interval and days open. To make complete data about the udder health, udder conformation traits need to be recorded. Likewise, the recording of feet and leg conformation traits is essential to assess lameness and locomotion traits of dairy animals. Precise recording of health, conformation and fertility traits is vital for higher selection accuracy in dairy cattle improvement programmes.

\section{Genetic parameters of functional traits Heritability}

Heritability estimates of functional traits are found in the range from very low to low. Heritability of different functional traits estimated during different periods are presented in (Table 1). Boettcher (2005) analysed the heritability estimates of calving interval, mastitis, retained placenta, longevity and cystic ovaries and confirmed the low heritable nature of functional traits. On his assessment of indicator traits like body condition score, somatic cell count, udder depth, teat length and foot angle, he revealed that the value of heritability estimates of indicator traits is higher when compared to their related direct functional traits. Hence, the indicator traits are considered as profoundly valuable attributes for getting higher accuracy of genetic evaluations when they are included alongside direct functional traits. Heritability estimates of feet and leg diseases are relatively less compared with those of feet and leg conformation traits (Buch et al. 2011). The range of recorded heritabilities of individual hoof diseases is found between 0.01 to 0.14 (Van der Spek et al. 2013; Malchiodi et al. 2017). The existing genetic variance in different functional traits is low but it has 
Table 1: Heritability estimates of functional traits.

\begin{tabular}{|c|c|c|c|}
\hline Trait & Breed & Heritability & Reference \\
\hline \multirow[t]{2}{*}{ Calving disorders } & Karan fries & $0.04-0.12$ & Sharma et al. $2011 \mathrm{~b}$ \\
\hline & Karan fries & $0.101-0.230$ & Balasundaram et al. 2011 \\
\hline \multirow[t]{2}{*}{ Still birth } & Crossbred cows and sahiwal & 0.014 & Singh and Singh, 1998 \\
\hline & Karan fries & 0.086 & Mukherjee et al. 1993 \\
\hline \multirow{3}{*}{ Calving ease direct } & Holstein & 0.12 & Eaglen et al. 2012 \\
\hline & Italian holstein & 0.08 & Pintus et al. 2013 \\
\hline & Holstein & 0.02 & Eaglen et al. 2012 \\
\hline \multirow[t]{3}{*}{ Calving ease maternal } & Italian holstein & 0.036 & Pintus et al. 2013 \\
\hline & Hariana & 0.20 & Sethi and Balaine, 1978 \\
\hline & Karan fries & 0.068 & Mukherjee et al. 1993 \\
\hline \multirow{3}{*}{ Retention of placenta } & Fleckvieh & 0.060 & Egger-Danner et al. 2015 \\
\hline & Holstein & 0.04 & Gernand et al. 2012 \\
\hline & Karan fries & 0.17 & Sharma et al. 2011a \\
\hline \multirow[t]{2}{*}{ Metritis } & Karan fries & 0.015 & Mukherjee et al. 1993 \\
\hline & Holstein & $0.006-0.262$ & Berry et al. 2014 \\
\hline \multirow{3}{*}{ Longevity } & Holstein & $0.080-0.084$ & Sasaki et al. 2012 \\
\hline & Norwegian red & 0.04 & Holtsmark et al. 2008 \\
\hline & Swedish red cows & 0.014 & Buch et al. 2010 \\
\hline \multirow[t]{2}{*}{ Clinical mastitis } & Holstein & 0.03 & Koek et al. 2014 \\
\hline & Holstein & $0.07-0.08$ & Urioste et al.2012 \\
\hline Repeat breeding syndrome & Karan fries & $0.07-0.19$ & Sharma et al. 2011c \\
\hline \multirow{3}{*}{ Somatic cell score } & Swedish red cows & 0.14 & Buch et al. 2010 \\
\hline & Dairy cattle breeds & $0.01-0.13$ & De Hass et al. 2008 \\
\hline & Holstein & 0.03 & Koek et al. 2014 \\
\hline Cystic ovary & Holstein & 0.06 & Gernand et al. 2012 \\
\hline \multirow{3}{*}{ Residual feed intake } & Holstein & $0.0-0.32$ & Pryce et al. 2014 \\
\hline & Dairy cattle breeds & $0.01-0.40$ & Connor, 2015 \\
\hline & Holstein & $0.016-0.070$ & Berry et al. 2014 \\
\hline Number of & Swedish red cows & 0.018 & Buch et al. 2010 \\
\hline inseminations/service & Swedish red and white breed & $0.022-0.031$ & Philipson and Lindhae, 2003 \\
\hline Age at first calving & Holstein & $0.07-0.024$ & Berry et al. 2014 \\
\hline Days from calving to first insemination & Swedish red cows & 0.038 & Buch et al. 2010 \\
\hline Calving interval & Karan fries & 0.15 & Dash et al. 2018 \\
\hline Service period & Karan fries & 0.18 & Dash et al. 2018 \\
\hline \multirow[b]{2}{*}{ Hoof diseases } & Swedish red cows & $0.03-0.05$ & Buch et al. 2011 \\
\hline & Fleckvieh & 0.02 & Fuerst-Waltl et al. 2012 \\
\hline Lameness & Holstein & 0.02 & Koek et al. 2014 \\
\hline Laminitis & Holstein & 0.06 & Gernand et al. 2012 \\
\hline Fore udder attachment & Italian holstein & 0.2 & Pintus et al. 2013 \\
\hline Teat length & Dairy cattle breeds & $0.09-0.15$ & Boettcher, 2005 \\
\hline Udder depth & Italian holstein & 0.3 & Pintus et al. 2013 \\
\hline
\end{tabular}

been reported as enough for selection of dairy animal ssuperior in those traits (Pryce et al., 1997; Miglior et al. 2017).

\section{Genetic correlation}

The relationship between milk yield traits and fertility traits were studied extensively and revealed it as antagonistic (VanRaden et al. 2004; Pryce et al. 2004). Due to this unfavorable genetic correlation, the practice of selection for high milk production deteriorates the fertility of dairy animals.
On realization of economic importance of fertility traits and their genetic relationship with production traits, the incorporation of fertility traits in selection programmes is becoming routine practice in many countries. The genetic relationship detailed between calving traits and reproduction traits is found to be positive. Heringstad et al. (2007) studied the relationship between stillbirth and calving difficulty and found direct relationship as 0.79 and maternal relationship as 0.62 . The relationship between maternal and direct effect of calving abnormalities is strong and negative (Thompson 
et al. 1981; Boldman and Famula, 1985). Hence, Dekker (1994) suggested to include both direct and maternal effects of calving abnormalities in index for the best results of sire selection.

The genetic correlation of somatic cell count $(0.60$ to 0.80 ) (Carlen et al. 2004), days from calving to first insemination $(0.38 \pm 0.05)$ and number of inseminations $(0.05$ \pm 0.06 ) (Buch et al. 2010) with mastitis were reported as positive. In the same range, genetic correlations for mastitis with other traits have also been estimated many times (Heringstad et al. 2006; Norberg et al. 2009). Based on the reported genetic correlation among health and conformation traits, some traits were identified as indicator traits of functional traits. Because of the strong positive correlation between somatic cell count and incidence of mastitis, the former trait is used as indicator trait for the later one. Similar relationship is reported between fertility traits and body condition scoring (BCS) and hence, BCS have been considered as indicator trait for fertility traits in genetic evaluations (Miglior et al. 2017). Udder conformation deformities and udder health problems adversely influence the functional longevity of milch cows. Dairy animals with low mammary score are highly prone for mammary injury and high risk of culling from the herd voluntarily. The genetic relationship reported between mastitis and milk yield is positive and found to be in the range from 0.35 to 0.56 (Kadermideen et al. 2000; Koivula et al. 2005; Koeck et al. 2014). Similar genetic correlation is revealed between incidence of cystic ovary and milk yield (Hooijer et al. 2001). These correlations demonstrated that the dairy cows predominant in milk production are more susceptible to mastitis and cystic ovaries.

Feet and leg problems were recorded as one of the common causes for involuntary culling of dairy animals. The genetic correlation reported between feet and leg diseases and longevity is negative (-0.42 to -0.43$)$ and strong (Nielsen et al. 1999). In this respect, the deviations in longevity of dairy animals is exhibited through the channel of existing genetic correlation of feet and leg diseases with milk production traits (Koenig et al. 2005). The value of genetic correlation recorded between feet and leg diseases and conformation traits is found in the range of low to moderate (Van der Waaij et al. 2005; Uggla et al. 2008). An assessment on genetic correlation between longevity and production traits by Sasaki (2013) showed the varying nature of genetic correlation across breeds, periods and countries. The existence of unfavourable genetic correlation between milk production traits and functional traits suggested that the simultaneous genetic selection for both types of traits is necessary for overall improvement of dairy animals.

\section{Genetic evaluation and selection of dairy animals for functional traits}

Impediments in selection of dairy animals for functional traits

Low heritability estimates of functional traits and difficulty in data recording are the common obstacles encountered in genetic evaluation programmes for functional traits. Recent advancements in data recording and computing methodologies increased the feasibility of genetic evaluation for functional traits. In genetic selection, higher accuracy can be expected if the heritability of the traits included is high. To increase the accuracy of selection for lowly heritable functional traits, the number of daughters per sire in evaluation need to be increased. Further, the inclusion of indicator traits having a high degree of genetic correlation with functional traits in selection will extend the accuracy. Incorporation of indicator traits like somatic cell count for mastitis, body condition scoring for metabolic disorders and, feet and leg traits for lameness and other locomotive disorders along with the direct functional traits in selection increases the accuracy of selection (Boettcher, 2005). Further, the use of genomic information of functional traits may overcome the problems of low heritability and difficult to record phenotypes.

\section{Genetic evaluation}

Use of precise information on relevant economically important traits including functional traits makes the genetic evaluations of dairy animals more accurate. Most of the functional traits are not normally distributed. Regardless of this fact, the linear models are regularly used in genetic evaluations because of their methodological simplicity. Animal model is most commonly used in estimation of breeding values of functional traits. For conformation traits and female fertility traits, animal model is the method of choice. However, the method often used for genetic analysis of longevity is survival analysis. Random regression models are useful for estimation of longitudinal breeding values for the traits like somatic cell count and milking speed. Threshold models have been tried for some of the functional traits like lameness (Boettcher et al. 1998), longevity (Boettcher et al. 1999), calving ease (Luo et al. 2002), mastitis (Rekaya et al. 2003) and fertility (Averill et al. 2004). The recent development, genomic selection, is highly suitable for difficult-to-measure functional traits, provided the size of reference cow population is large enough. For higher accuracy of prediction, genomic information of indicator traits may also be used in genomic selection (Pryce et al. 2018).

\section{Considerations for estimation of economic values of functional traits}

In breeding programmes, selection of traits and weighting factor to each selected trait are emphasized for improvement of animals. The weighting factor applied to each trait is called as economic value and it decides how much to be improved in the selected trait (Groen et al. 1997). Treatment expense and milk loss are commonly considered for the assessment of economic losses due to health problems. The treatment expenditure includes number of days animal in disease, veterinarian charge and price of medicines used. For multiple incidences of a disease, cost of that disease may be arrived by multiplying per incidence cost with number of 
incidences. Cost of extra labour working hours is also included in cost per incidence. The reduction in quantity of milk produced due to a health problem is weighed as milk lost. Price of milk is considered for conversion of quantity of milk lost to the monetary value. For the estimation of economic value of fertility traits, cost of insemination, cost of hormones or medicines and veterinarian charge are considered as influencing factors (Kargo et al. 2014). Economic value of functional traits varies with the production circumstances and methods applied for calculation. Accurate estimation of economic values of functional traits facilitates the precise genetic evaluation.

\section{Total merit index for selection}

In multi-traits selection, an index value is calculated from breeding values of economically important traits and their economic values for genetic selection. A new method of selection index called total merit index is widely practiced in dairy advanced countries. Total merit index is a combined index in which the typical selection index values derived for different traits groups are aggregated. In breeding goals of modern dairy production systems, more functional traits are included along with several economically important performance traits (Pfeiffer et al. 2015). These traits are grouped into distinguished categories viz., milk production traits, growth traits, fertility traits, calving traits, udder health traits, claw health traits, conformation traits, temperament traits and longevity. For each category, a typical selection index is constructed and these indices are called as subindices of the total merit index. Each sub index is multiplied by a weighting factor and summed all to get a single value. This value is called as total merit index which provides the estimated breeding value of dairy animals. In total merit index, the weighting factor for each group of traits are decided based on the breeding goal of the programme or the country. Total merit indices used in different countries are varying in their composition like number of traits category used, type and number of traits used in each category and weights given to each sub index. The total merit indices developed from Spain, The Netherlands-Flanders, Nordic countries, Poland, Germany and USA are Indice de Merito Genetico Total (ICO), Netherland Cattle Improvement Index (NVI), Nordic Total Merit index (NTM), production and functionality index (PF), Relativ-Zuchtwert Gesamt (RZG) and net merit index (NM) respectively (Egger-Danner et al. 2015). Among the different indices, functional traits are included much earlier in NTM.

In Nordic countries, animal recording system is well established for functional traits, in line with the recoding system for performance traits. The total merit index, NTM is used for the selection of Nordic red breeds, Holstein and Jersey cattle. Around 60 traits have been used under 14 categories. The breeding scheme with NTM have yielded higher lactation milk production, improved fertility and reduced incidence of diseases. Improvement in animals were recorded as 73.4 per cent of 60 day non-return rate, seven per cent of reduction in the incidence of mastitis from
28 to 21 per cent and less than 2 per cent of incidence of calving difficulties (FAO, 2007).

The criteria, Annual Monetary Genetic Gain (AMGG) is used for evaluation of different total merit indices. AMGG is described as 'the monetary superiority per year of the progeny of the selected animals after one selection cycle in the breeding unit' (Willam et al. 2002). It is reported that the inclusion of functional traits in total merit index of different breeding programmes has positive effect on AMGG. Inclusion of functional traits increased the AMGG to $11 \%$ in Simmental cows and to $17 \%$ in Brown-Swiss cows (Willam et al. 2002). A comparative study by Thomasen et al. (2014) declared that the contribution of functional traits to AMGG in different breeding schemes is significant and highest $(36.2 \%)$ in turbo breeding scheme.

\section{CONCLUSION}

Health of dairy animals is being realized as one of the central building blocks of healthy milk production system which favours animals as well as producers and consumers. Another building block, fertility of dairy animals is vital for economically sustainable dairy farming. Desirable temperament traits of dairy animals make the management easy and effective. The high producing dairy animals sound in functional traits progress the owners to economically wealthy state and provide healthy food to consumers. Hence, the improvement of dairy animals for functional traits is inevitable for establishment of healthy milk production system. Obstacles in evaluation for functional traits have been overcome by the new methods and technologies emerged in the area of dairy cattle breeding. The new developments like, genomic selection, automated recording systems, advancements in data analysis tools and identification of better indicator traits, and other emerging technologies have been increasing the efficiency of genetic evaluation for functional traits. Establishment of accurate data recording system and use of efficient method of genetic evaluation for functional traits and other economic traits may favour the overall development of dairy sector in the developing countries like India.

\section{REFERENCES}

Averill, T.A., Rekaya, R. and Weigel, K. (2004). Genetic analysis of male and female fertility using longitudinal binary data. Journal of Dairy Science. 87: 3947-3952.

Balasundaram, B., Gupta, A.K., Dongre, V.B., Mohanty, T.K., Sharma, P.C., Khat, K. and Singh, R.K. (2011). Influence of genetic and non-genetic factors on incidence of calving abnormalities in Karan Fries cows. Indian Journal of Animal Research. 45: 26-31.

Berry, D.P., Wall, E. and Pryce, J.E. (2014). Genetics and genomics of reproductive performance in dairy and beef cattle. Animal. 8: 105-121.

Bicalho, R.C., Galvao, K.N., Warnick, L.D. and Guard, C.L. (2008). Stillbirth parturition reduces milk production in Holstein cows. Preventive Veterinary Medicine. 84: 112-120. 
Boettcher, P. (2005). Breeding for improvement of functional traits in dairy cattle. Italian Journal of Animal Science. 4: 7-16.

Boettcher, P.J., Dekkers, J.C.M., Warnick, L.D. and Wells, S.J. (1998). Genetic analysis of clinical lameness in dairy cattle. Journal of Dairy Science. 81: 1148-1156.

Boettcher, P.J., Jairath, L.K. and Dekkers, J.C.M. (1999). Comparison of methods for genetic evaluation of sires for survival of their daughters in the first three lactations. Journal of Dairy Science. 82: 1034-1044.

Boichard, D. (1990). Estimation of economic value of conception rate in dairy cattle. Livestock Production Science. 24: 187-204.

Boldman, K.G. and Famula, T.R. (1985). Association of sire dystocia transmitting ability with progeny linear type traits in Holsteins. Journal of Dairy Science. 68: 2052-2057.

Buch, L.H., Sørensen, A.C., Lassen, J., Berg, P., Eriksson, J.A., Jakobsen, J.H. and Sørensen, M.K. (2011). Hygienerelated and feed-related hoof diseases show different patterns of genetic correlations to clinical mastitis and female fertility. Journal of Dairy Science. 94: 1-12.

Buch, L.H., Sørensen, O.M., Lassen, J., Berg, P., Jakobsen, J.H., Johansson, K. and Sørensen, A.C. (2010). Udder health and female fertility traits are favourably correlated and support each other in multi-trait evaluations. Journal of Animal Breeding and Genetics. 128: 174-182.

Carlén, E., Strandberg, E. and Roth, A. (2004). Genetic parameters for clinical mastitis, somatic cell score, and production in the first three lactations of Swedish Holstein cows. Journal of Dairy Science. 87: 3062-3070.

Charfeddine, N. and Perez-Cabal, M.A. (2017). Effect of claw disorders on milk production, fertility and longevity and their economic impact in Spanish Holstein cows. Journal of Dairy Science. 100: 653-664.

Connor, E.E. (2015). Invited review: Improving feed efficiency in dairy production: Challenges and possibilities. Animal. 9: 395-408.

Dash, S.K., Gupta, A.K., Singh, A., Chakravarty, A.K., Singh, M. and Kumar, V. (2018). Performance appraisal and genetic parameter estimation of all lactation traits in Karan Fries cattle. Indian Journal of Animal Research. 52: 7-12.

De Haas, Y., Ouweltjes, W., Ten Napel, J., Windig, J.J. and De Jong, G. (2008). Alternative somatic cell count traits as mastitis indicators for genetic selection. Journal of Dairy Science. 91: 2501-2511.

Dekkers, J.C.M. (1994). Optimal breeding strategies for dystocia. Journal of Dairy Science. 77: 3441-3453.

Ducrocq, V., Quaas, R.L., Pollak, E. and Casella, G. (1988). Length of productive life of dairy cows. 1. Justification of a Weibull model. Journal of Dairy Science. 71: 3061-3070.

Eaglen, S.A., Coffey, M.P., Woolliams, J. and Wall, E. (2012). Evaluating alternate models to estimate genetic parameters of calving traits in United Kingdom HolsteinFriesian dairy cattle. Genetics Selection Evolution. 44: 23.

Egger-Danner, C., Cole, J.B., Pryce, J.E., Gengler, N., Heringstad, B., Bradley, A. and Stock, K.F. (2015). Invited review: overview of new traits and phenotyping strategies in dairy cattle with a focus on functional traits. Animal. 9: 191207.
FAO (2007). The state of the world's animal genetic resources for food and agriculture. Final report of Eleventh Regular Session. 344-383.

Fuerst-Waltl, B., Fuerst, C. and Egger-Danner, C. (2012). Claw health diagnoses in the routine health monitoring system of Austrian Fleckvieh cattle. $63^{\text {rd }}$ Annual Meeting of the Association of European Animal Production, Bratislava, Slovakia.

Gernand, E., Rehbein, P., Von Borstel, U.U. and König, S. (2012). Incidences of and genetic parameters for mastitis, claw disorders and common health traits recorded in dairy cattle contract herds. Journal of Dairy Science. 95: 2144-2156.

Groen, A.F. (1996). Genetic improvement of functional traits in cattle. Report from EU concerted action GIFT. Interbull Bulletin. 22.

Groen, A.F., Steine, T., Colleau, J.J., Pedersen, J., Pribyl, J. and Reinsch, N. (1997). Economic values in dairy cattle breeding, with special reference to functional traits. Report of an EAAP-working group. Livestock Production Science. 49: 1-21.

Heringstad, B., Chang, Y.M., Andersen-Ranberg, I.M. and Gianola, D. (2006). Genetic analysis of number of mastitis cases and number of services to conception using a censored threshold model. Journal of Dairy Science. 89: 4042- 4048.

Heringstad, B., Klemetsdal, G. and Steine, T. (2007). Selection responses for disease resistance in two selection experiments with Norwegian red cows. Journal of Dairy Science. 90: 24192426.

Hogeveen, H., Huijps, K. and Lam, T.J.G.M. (2011). Economic aspects of mastitis: New developments. New Zealand Veterinary Journal. 59: 16-23.

Holtsmark, M., Heringstad, B., Madsen, P., Odegard, J. (2008). Genetic relationship between culling, milk production, fertility and health traits in Norwegian Red cows. Journal of Dairy Science. 91: 4006-4012.

Hooijer, G.A., Lubbers, R.B., Ducro, B.J., Van Arendonk, J.A., KaalLansbergen, L.M. and Van Der Lende, T. (2001). Genetic parameters for cystic ovarian disease in Dutch Black and White dairy cattle. Journal of Dairy Science. 84: 286-291.

Huxley, J.N. (2013). Impact of lameness and claw lesions in cows on health and production. Livestock Science. 156: 64-70.

ICAR (2019). International Committee for Animal Recording - Guidelines. Section 7: Bovine functional traits. Online available at https://www.icar.org/Guidelines/07-Bovine-FunctionalTraits. pdf (accessed 5 May 2020).

Jingar, S.C. (2013). Incidence of mastitis and its impact on milk production performance traits in Dairy animals. PhD Thesis, National Dairy Research Institute, Karnal, Haryana.

Kadermideen, N., Thompson, R. and Simm, G. (2000). Linear and threshold model genetic parameters for disease, fertility, and milk production in dairy cattle. Animal Science. 71 : 411-419.

Kargo, M., Hjortø, L., Toivonen, M., Eriksson, J.A., Aamand, G.P. and Pedersen, J. (2014). Economic basis for the Nordic Total Merit Index. Journal of Dairy Science. 97: 7879-7888.

Koeck, A., Loker, S., Miglior, F., Kelton, D.F., Jamrozik, J. and Schenkel, F.S. (2014). Genetic relationships of clinical mastitis, cystic ovaries and lameness with milk yield and somatic cell score in first-lactation Canadian Holsteins. Journal of Dairy Science. 97: 5806-5813. 
Koenig, S., Scharifi, A.R., Wentrot, H., Landmann, D., Eise, M. and Simianer, H. (2005). Genetic parameters of claw and foot disorders estimated with logistic models. Journal of Dairy Science. 88: 3316-3325.

Koivula, M., Mäntysaari, E.A., Negussie, E. and Serenius, T. (2005). Genetic and phenotypic relationships among milk yield and somatic cell count before and after clinical mastitis. Journal of Dairy Science. 88: 827-833.

Kumar, A., Singh, U., Alex, R. and Kumar, S. (2017). Risk factors associated with abnormal parturition and their effects on production and reproductive performance in Frieswal cattle of India. Indian Journal of Animal Research. 51: 242-246.

Luo, M.F., Boettcher, P.J., Schaeffer, L.R. and Dekkers J.C.M. (2002). Estimation of genetic parameters of calving ease in first and second parities of Canadian Holsteins using Bayesian methods. Livestock Production Science. 74: 175-184.

Malchiodi, F., Koeck, A., Mason, S., Christen, A.M., Kelton, D.F., Schenkel, F.S. and Miglior, F. (2017). Genetic parameters for hoof health traits estimated with linear and threshold models using alternative cohorts. Journal of Dairy Science. 100: 2828-2836.

Miglior, F., Fleming, A., Malchiodi, F., Brito, L.F., Martin, P. and Baes, C.F. (2017). A 100-year review: identification and genetic selection of economically important traits in dairy cattle. Journal of Dairy Science. 100: 10251-10271.

Mukherjee, K., Tomar, S.S. and Sadana, D.K. (1993). Factors affecting reproduction disorders and their association in Karan Fries herd. Indian Veterinary Journal 70: 121-124.

Nielsen, U.S., Pedersen, G.A., Pedersen, J. and Jensen, J. (1999). Genetic variation in disease traits and their relationships with survival in Danish dairy cattle. Interbull Bulletin. 21: 170-177.

Norberg, E., Madsen, P. and Pedersen, J. (2009). A multi-trait genetic analysis of protein yield, udder health and fertility in first lactation Danish Holstein, Danish Red and Danish Jersey using an animal model. Acta Agriculturae Scandinavica, Section A-Animal Science. 59: 197-203.

Pfeiffer, C., Fuerst-Waltl, B., Schwarzenbacher, H., Steininger, F. and Fuerst, C. (2015). A comparison of methods to calculate a total merit index using stochastic simulation. Genetics Selection Evolution. 47: 36 .

Philipson, J. and Lindhae, B. (2003). Experiences of including reproduction and health traits in Scandinavian dairy cattle breeding programmes. Livestock Production Science. 83: 99-112.

Pintus, M.A., Nicolazzi, E.L., Van Kaam, J.B., Biffani, S., Stella, A., Gaspa, G. Dimauro, C. and Macciotta, N.P. (2013). Use of different statistical models to predict direct genomic values for productive and functional traits in Italian Holsteins. Journal of Animal Breeding and Genetics. 130: 32-40.

Pryce, J.E., Nguyen, T.T.T., Axford, M., Nieuwhof, G. and Shaffer, M. (2018). Symposium review: Building a better cow The Australian experience and future perspectives. Journal of Dairy Science. 101: 3702-3713.

Pryce, J.E., Royal, M.D., Garnsworthy, P.C. and Mao, I.L. (2004). Fertility in the high-producing dairy cow. Livestock Production Science. 86: 125-135.
Pryce, J.E., Wales, W.J., de Haas, Y., Veerkamp, R.F. and Hayes, B.J. (2014). Genomic selection for feed efficiency in dairy cattle. Animal. 8: 1-10.

Pryce, J.E., Veerkamp, R.F., Thompson, R., Hill, W.G., and Simm, G. (1997). Genetic aspects of common health disorders and measures of fertility traits in Holstein Friesian dairy cattle. Journal of Animal Science. 65: 353-360.

Rekaya, R., Gianola, D. and Shook, G. (2003). Longitudinal random effects models for genetic analysis of binary data with application to mastitis in dairy cattle. Genetics Selection Evolution. 35: 457-468.

Sasaki, O. (2013). Estimation of genetic parameters for longevity traits in dairy cattle: A review with focus on the characteristics of analytical models. Animal Science Journal. 84: 449460 .

Sasaki, O., Aihara, M., Hagiya, K., Nishiura, A., Shii, K., Satoh, M. (2012). Genetic evaluation of the longevity of the Holstein population in Japan using a Weibull proportional hazard model. Animal Science Journal. 83: 95-102.

Sethi, R.K. and Balaine, D.S. (1978). An approach to quantification of threshold traits in dairy cattle. Indian Journal of Dairy Science. 48: 344

Sharma, P.C., Gupta, A.K., Mohanty, T.K., Chakravarty, A.K., Singh, A. and Chand, S. (2011a). Uterine and ovarian health traits in Karan Fries cows. Indian Veterinary Journal. 88: 83.

Sharma, P.C., Gupta, A.K., Mohanty, T.K., Chakravarty, A.K., Singh, A., Sharma, A.K. and Balasundaram, B. (2011c). Genetic analysis of Female Fertility health traits in Karan Fries cows. Indian Journal of Animal Reproduction. 32: 19 22.

Sharma, P.C., Gupta, A.K., Mohanty, T.K., Chakravarty, A.K., Singh, A., Sharma, A.K., Tomar, K.P.S., Balasundaram, B., Singh, Y. (2011b). Genetics of calving health traits of Karan Fries crossbred cows. Indian Journal of Dairy Science. 64: 412 416.

Simianer, H., Solbu, H. and Schaeffer, L.R. (1991). Estimated genetic correlations between disease and yield traits in dairy cattle. Journal of Dairy Science. 74: 4358-4365.

Singh, C.V. and Singh, R.V. (1998). Genetic parameters of different reproductive disorders in crossbred and Sahiwal cattle. Indian Journal of Animal Science. 68: 494-495.

Thomasen, J.R., Egger - Danner, C., Willam, A., Gulbrandtsen. B., Lund, M.S. and Serensen, A.C. (2014). Genomic selection strategies in a small dairy cattle population evaluated for genetic gain and profit. Journal of Dairy Science. 97: 458 -470 .

Thompson, J.R., Freeman, A.E. and Berger, P.J. (1981). Age of dam and maternal effects for dystocia in Holsteins. Journal of Dairy Science. 64: 1603-1609.

Uggla, E., Jakobsen, J.H., Bergsten, C., Eriksson, J.Å. and Strand -berg, E. (2008). Genetic correlations between claw health and feet and leg conformation traits in Swedish dairy cows. Interbull Bulletin. 38: 91-95.

Urioste, J.I., Franzen, J., Windig, J.J. and Strandberg, E. (2012). Genetic relationships among mastitis and alternative somatic cell count traits in the first 3 lactations of Swedish Hosteins. Journal of Dairy Science. 95: 3428-3434. 
Van der Spek, D., Van Arendonk, J.A., Vallée, A.A. and Bovenhuis, $H$. (2013). Genetic parameters for claw disorders and the effect of preselecting cows for trimming. Journal of Dairy Science. 96: 6070-6078.

Van der Waaij, E.H., Holzhauer, M., Ellen, E., Kamphuis, C. and de Jong, G. (2005). Genetic parameters for claw disorders in Dutch dairy cattle and correlations with conformation traits. Journal of Dairy Science. 88: 3672-3678.

VanRaden, P.M., Sanders, A.H., Tooker, M.E., Miller, R.H., Norman, H.D., Kuhn, M.T. and Wiggans, G.R. (2004). Development of a national genetic evaluation for cow fertility. Journal of Dairy Science. 87: 2285-2292.
Wathes, D.C. (2012). Mechanisms Linking Metabolic Status and Disease with Reproductive Outcome in the Dairy Cow. Reproduction in Domestic Animals. 47: 304-312.

Willam, A., Egger-Danner, C., Sölkner, J. and Gierzinger, E. (2002). Optimization of progeny testing schemes when functional traits play an important role in the total merit index. Livestock Production Science. 77: 217-225. 